Metals and Ceramics Division

\title{
MATERIALS CORROSION IN AMMONIA/SOLID HEAT PUMP WORKING MEDIA
}

\author{
D. F. Wilson \\ M. Howell \\ J. H. DeVan
}

Date Published: January 1992

NOTICE: This document contains information of a preliminary nature. It is subject to revision or correction and therefore does not represent a final report.

Prepared for the

U.S. Department of Energy

Assistant Secretary for Conservation and Renewable Energy

Office of Industrial Technologies

ED 0112000

\section{Prepared by the}

OAK RIDGE NATIONAL LABORATORY

Oak Ridge, Tennessee 37831-6285

managed by

MARTIN MARIETTA ENERGY SYSTEMS, INC.

for the

U.S. DEPARTMENT OF ENERGY

under contact DE-AC05-84OR21400 


\section{CONTENTS}

Page

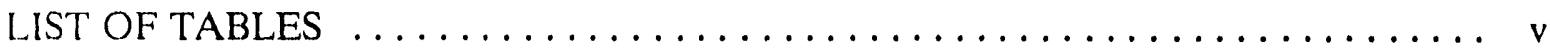

LIST OF FIGURES $\ldots \ldots \ldots \ldots \ldots \ldots \ldots \ldots \ldots \ldots \ldots \ldots \ldots \ldots \ldots \ldots \ldots \ldots$

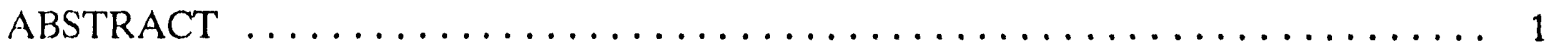

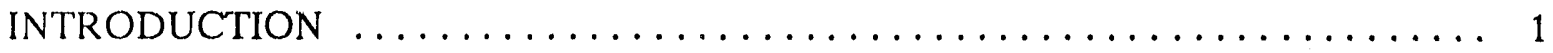

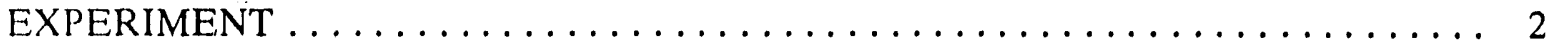

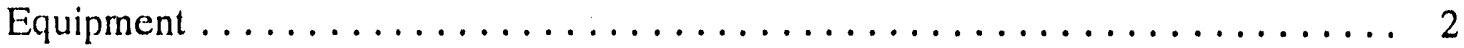

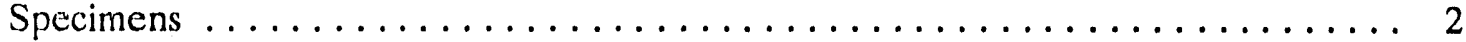

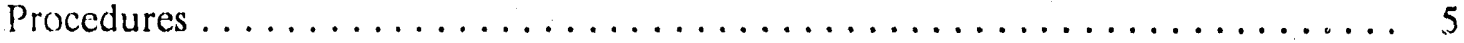

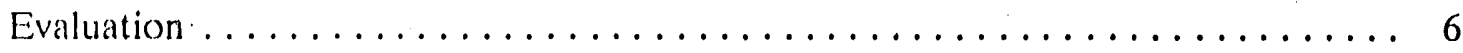

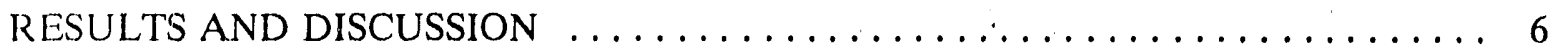

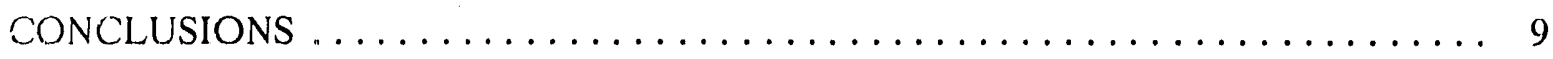

REFERENCES ................................ 9 


\section{LIST OF TABLES}

Tiahle $\quad \underline{\text { Page }}$

1 Nominal chemical composition (wt $\%$ ) of the materials tested .......... 5

2 Test parameters used in this corrosion study $\ldots \ldots \ldots \ldots \ldots \ldots \ldots \ldots \ldots$

3 Appearance of materials after exposure to salt complexes.

Materials and salt complexes are listed in order of their

corrosion resistance and corrosivity, respectively $\ldots \ldots \ldots \ldots \ldots \ldots$ 


\section{LIST OF FIGURES}

Figure

Page

1 Test cell showing two reaction vessels and associated heaters,

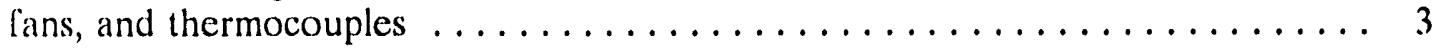

2 Test system showing four cells and associated control, measuring, and recording devices $\ldots \ldots \ldots \ldots \ldots \ldots \ldots \ldots \ldots \ldots$

3 Change in pressure for an ammonia/ $\mathrm{CaBr}_{2}$ complex for two connected reactors that were sequentially heated to $189^{\circ} \mathrm{C}$ and cooled to room temperature out of phase with each other . 


\title{
MATERIALS CORROSION IN AMMONIASSOLID HEAT PUMP WORKING MEDIA*
}

\author{
D. F. Wilson, M. Howell, and J. H. DeVan
}

\begin{abstract}
Salt/ammonia complexes will undergo thermal cycles during use as working media for heat pumps. The interaction between container materials and complexes under thermal cyclic conditions was assessed to screen possible containment materials. Aluminum alloys 3003,1100 , and 6063 and carbon steel A214 were tested against possible heat pump working media $\mathrm{SrCl}_{2} / \mathrm{NH}_{3}, \mathrm{CaBr}_{2} / \mathrm{NH}_{3}$, and $\mathrm{CaCl}_{2} / \mathrm{NH}_{3}$. None of the containment materials showed susceptibility to stress corrosion cracking. While all the materials demonstrated excellert general corrosion resistance to $\mathrm{SrCl}_{2} / \mathrm{NH}_{3}$, only $\mathrm{A} 214$ displayed good general corrosion resistance to $\mathrm{CaCl}_{2} / \mathrm{NH}_{3}$. The complex $\mathrm{CaBr} / \mathrm{NH}_{3}$ was found to be subject to thermal cyclic instability and should not be used as a heat pump working medium.
\end{abstract}

\section{INTRODUCTION}

Coordination complexes, of use as heat pump working media, are formed from thermochemical reactions between a solid metal inorganic salt (adsorbent) and a refrigerant gas (adsorbate). The overall process can be written as:

$$
\text { Salt + Gas * Salt•Gas. }
$$

The adsorption (formation of the complex) process is an exothermic reaction, and the desorption process is an endothermic one. The proper cyclic combination of temperature and pressure differentials, and heat fluxes to drive the complexing reaction reversibly, allows for waste heat recovery or useful refrigeration. The operation of salt/gas systems with vapor pressures,

*Research sponsored by the U.S. Department of Energy, Assistant Secretary for Conservation and Renewable Energy, Office of Industrial Technologies, Industrial Energy Efficiency Division, under contract DE-AC05-84OR21400 with Martin Marietta Energy Systems, Inc. 
independent of the gas concentration over wide ranges of gas concentrations, ${ }^{1}$ allows for high temperature lifts and coefficient of performance in heat pumps. The performance of an actual system is dependent not only on the surface sorption reaction, but also on the quantity of the salt that has complexed.

Rocky Research Corporation is in the process of demonstrating the effectiveness of complex salt/ammonia systems for use as industrial heat pumps. In order to better project the cost and lifetime of the heat pump system, the compatibility of the proposed construction matcrials with the preferred complex salts/ammonia systems must be demonstrated. Rocky Research Corporation has selected three complexes $\left(\mathrm{SrCl}_{2} / \mathrm{NH}_{3}, \mathrm{CaBr} 2 / \mathrm{NH}_{3}\right.$, and $\left.\mathrm{CaCl}_{2} / \mathrm{NH}_{3}\right)$ and four materials of construction (aluminum alloys 3003, 1100, and 6063 and carbon steel A214). Corrosion and stress corrosion testing were performed at the Oak Ridge National Laboratory to assess matcrials compatibility.

\section{EXPERIMEN'T}

\section{Equipment}

The experimental equipment is shown in Fig. 1. Each cell, consisting of two interconnected steel vessels, allowed for the charging and discharging of the ammonia gas from one vessel into another as the temperatures of the two vessels were eycled out of phase. The cells, as valved, allowed for the addition of ammonia gas and venting for the release of excessive pressure. The stecl vessels were surrounded by clam-shell heaters and furnished with fans for forced cooling from below. Associated temperature control, over-temperature, and measuring thermocouples are also displayed in Fig. 1. Metallic shields, which are not shown, enclosed the heaters and fans. The heaters and fans were activated and deactivated via programmable controllers. As instrumented, the system allowed for continuous monitoring and recording of temperatures and pressures of lour test cells (Fig. 2).

Specimens

The materials tested were aluminum alloys 3003, 1100, and 6063 and carbon steel A214. Typical compositions of these materials are shown in Table 1. C-ring* test specimens were made by Metal Samples Company Incorpo' ated ${ }^{\dagger}$ from materials they had sourced.

\footnotetext{
*Specimen design conforms to American Society for Testing Materials (ASTM) standard recommended practices as defined in ASTM G 38-73.

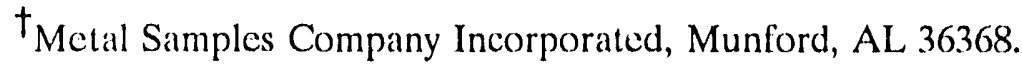




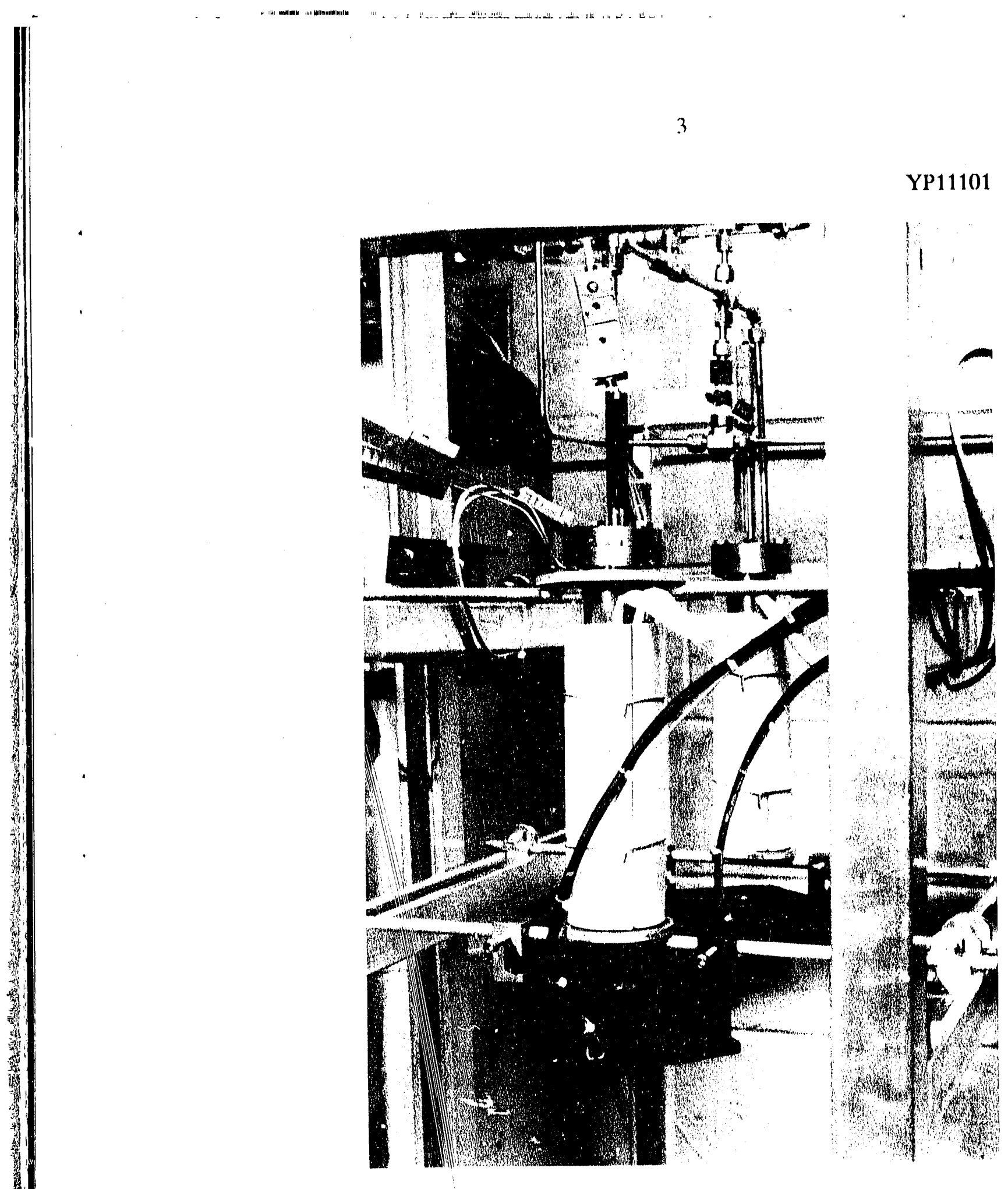

Fig. 1. Test cell showing two reaction vessels and associated heaters, lans, and thermocouples. 


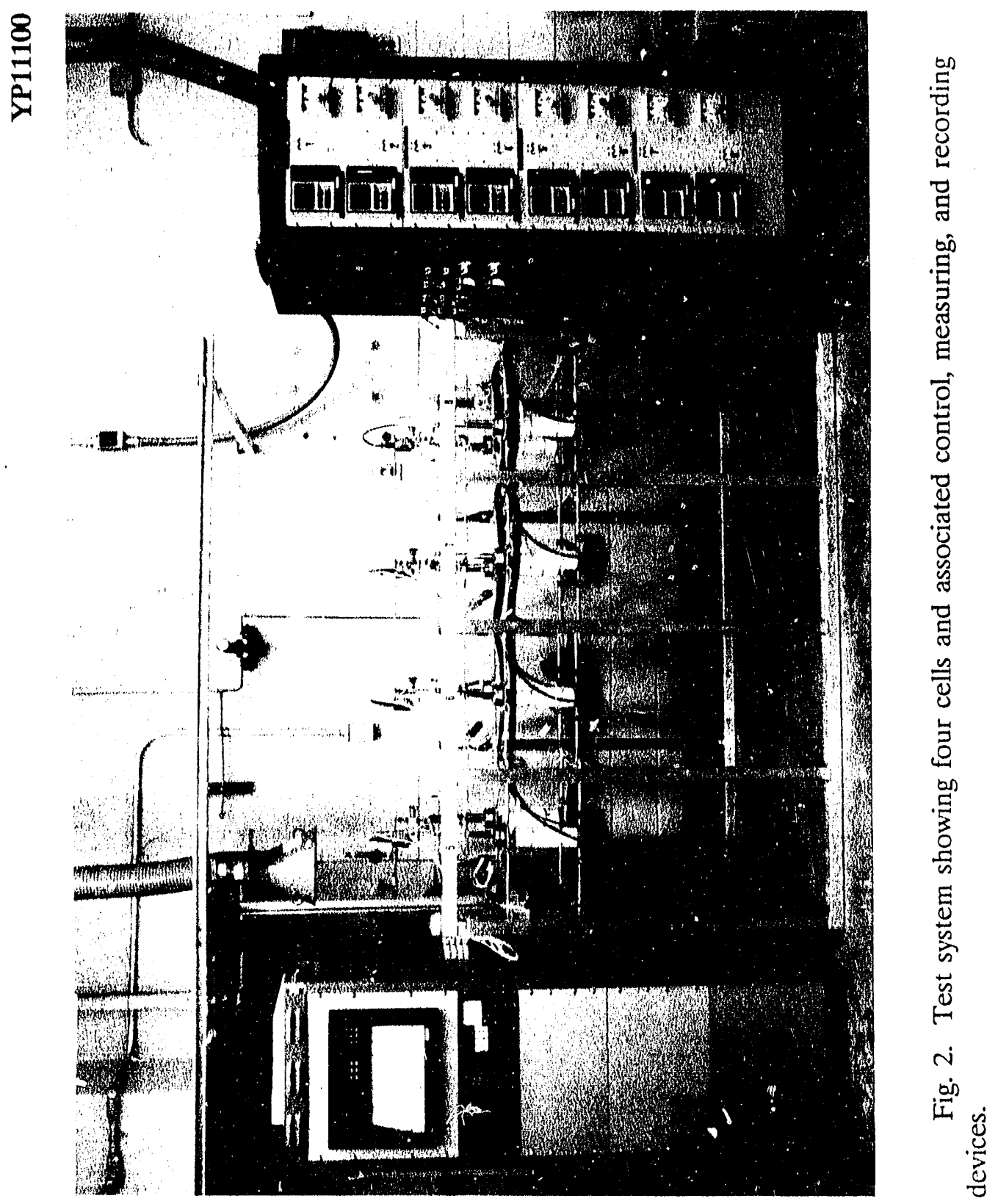


Table 1. Nominal chemical composition (wt \%)

of the materials tested

\begin{tabular}{|c|c|c|c|c|}
\hline \multirow[b]{2}{*}{ Element } & \multicolumn{4}{|c|}{ Materials $^{a}$} \\
\hline & Al 3003 & Al 1100 & $\mathrm{Al} 6063$ & Steel A214 \\
\hline $\mathrm{Si}$ & $0.6 \max$ & $0.95 \max$ & 0.60 to 0.20 & \\
\hline $\mathrm{Fe}$ & $0.7 \max$ & & $0.35 \mathrm{max}$ & Remainder \\
\hline $\mathrm{Cu}$ & 0.20 to 0.05 & 0.20 to 0.05 & $0.10 \max$ & \\
\hline $\mathrm{Mn}$ & 1.5 to 1.0 & 0.05 & $0.10 \max$ & 0.420 \\
\hline $\mathrm{Zn}$ & 0.10 & 0.10 & $0.10 \max$ & \\
\hline $\mathrm{Mg}$ & & & 0.9 to 0.45 & \\
\hline $\mathrm{Cr}$ & & & $0.10 \max$ & \\
\hline $\mathrm{Ti}$ & & & $0.10 \max$ & \\
\hline $\mathrm{C}$ & ! & & & 0.090 \\
\hline $\mathrm{P}$ & & & & 0.005 \\
\hline$S$ & & & & 0.006 \\
\hline $\mathrm{Al}$ & Remainder & Remainder & Remainder & \\
\hline Others & $0.15 \max$ & $0.15 \max$ & $0.15 \mathrm{max}$ & \\
\hline
\end{tabular}

"Source: Metals Samples Company Incorporated.

\section{Procedures}

A stainless steel bolt fitted with ceramic insulators was inserted through the holes of the $C$-ring and tightened such that the outer diameter of the ring was reduced by $1.3 \mathrm{~mm}(0.050 \mathrm{in}$.). This procedure ensured that the material opposite the opening was stressed to its yield point, thus providing the necessary stress for stress corrosion cracking if such was inherent to the material/complex salt/ammonia systems. One C-ring of each $n$. terial was stressed and archived in a desiccator as a control.

Each vessel of a cell was loaded with two degreased, C-ring, stressed, wcimens and a predetermined weight of the same salt. The weight was chosen so as to completely cover the specimens and minimize the post ammoniation dead space in the vessels. The cells were evacuated $[\sim 17.33 \mathrm{~Pa}(0.0025 \mathrm{psi})]$ and the vessels heated to the salt-ammoniating temperature. The vessels were maintained at temperature under dynamic vacuum overnight. The following day, the system was pressurized with ammonia to a pressure slightly above the calculated equilibrium pressure for at least $4 \mathrm{~h}$. Monitoring of the temperature changes (increasing and then decreasing) as complexing occurred provided a very good indication of the end of reaction. At the end of complexing, the cells were checked for leaks (wet pH paper) and thermal cycling begun. 
Each 9-h cycle consisted of: (a) heating to operating temperature, (b) holding at operating icmperature, (c) cooling to room temperature, and (d) holding at room temperature. Since the vessels were cycled out of phase, during the cool-down phase of one vessel, there is a secondary temperature spike due to ammonia charging from the other vessel, which is in its heat-up phase. The ammoniating temperatures and pressures and the operating temperatures of the salt complexes are presented in Table 2.

Table 2. Test parameters used in this corrosion study

\begin{tabular}{|c|c|c|c|}
\hline \multirow[b]{2}{*}{ Parameter } & \multicolumn{3}{|c|}{ Salt complexes } \\
\hline & $\mathrm{SrCl}_{2}$ & $\mathrm{CaCl}_{2}$ & $\mathrm{CaBr}_{2}$ \\
\hline $\begin{array}{l}\text { Ammoniating } \\
\text { lemperature }\end{array}$ & $333 \mathrm{~K}\left(60^{\circ} \mathrm{C}\right)$ & $323 \mathrm{~K}\left(50^{\circ} \mathrm{C}\right)$ & $398 \mathrm{~K}\left(125^{\circ} \mathrm{C}\right)$ \\
\hline $\begin{array}{l}\text { Ammoniating } \\
\text { pressure }\end{array}$ & 0.34 MPa (49 pri) & $0.26 \mathrm{MPa}(38 \mathrm{psi})$ & $0.37 \mathrm{MPa}(54 \mathrm{psi})$ \\
\hline $\begin{array}{l}\text { Operating } \\
\text { lemperature } \\
\text { (max) }\end{array}$ & $389 \mathrm{~K}\left(116^{\circ} \mathrm{C}\right)$ & $380 \mathrm{~K}\left(107^{\circ} \mathrm{C}\right)$ & $462 \mathrm{~K}\left(189^{\circ} \mathrm{C}\right)$ \\
\hline I.cength of test & $2352 \mathrm{~h}$ & $2496 \mathrm{~h}$ & $2496 \mathrm{~h}$ \\
\hline
\end{tabular}

Evaluation

At the conclusion of testing, the specimens were cleaned and subjected to optical microscopic examination.

\section{RESULTS AND DISCUSSION}

There was corrosion failure of a silver-plated copper gasket in one of the reactors holding the $\mathrm{CaCl}_{2}$ complex, resulting in loss of ammonia. The greenish corrosion product observed was indicative of an ammonia/copper reaction and was the result of a pin hole in or damage to the silver plate. After replacement of this gasket, the system was re-ammoniated and returned to the lest mode. 
Examination of the recorded temperature and pressure profiles revealed no change in these profiles with time except for the $\mathrm{CaBr}_{2}$ complex, indicating that the reaction vessels were properly sealed and that two of the salt complexes behaved in a reproducible manner. In the case of the $\mathrm{CaBr}_{2}$ complex, a trend of increasing pressure with number of test cycles, as presented in Fig. 3 , was observed. This increasing pressure, indicative of an unstable salt/ammonia complex, may preclude the use of this complex in heat pump applications. Instability may be due to deactivation of surface sorption sites or compaction of the salt (decrease in the quantity of salt complexed). The differences in percentage change in pressure shown in Fig. 3 are most likely due to slight differences in the amount of salt initially added to the vessels.

ORNL-DWG 91-9736

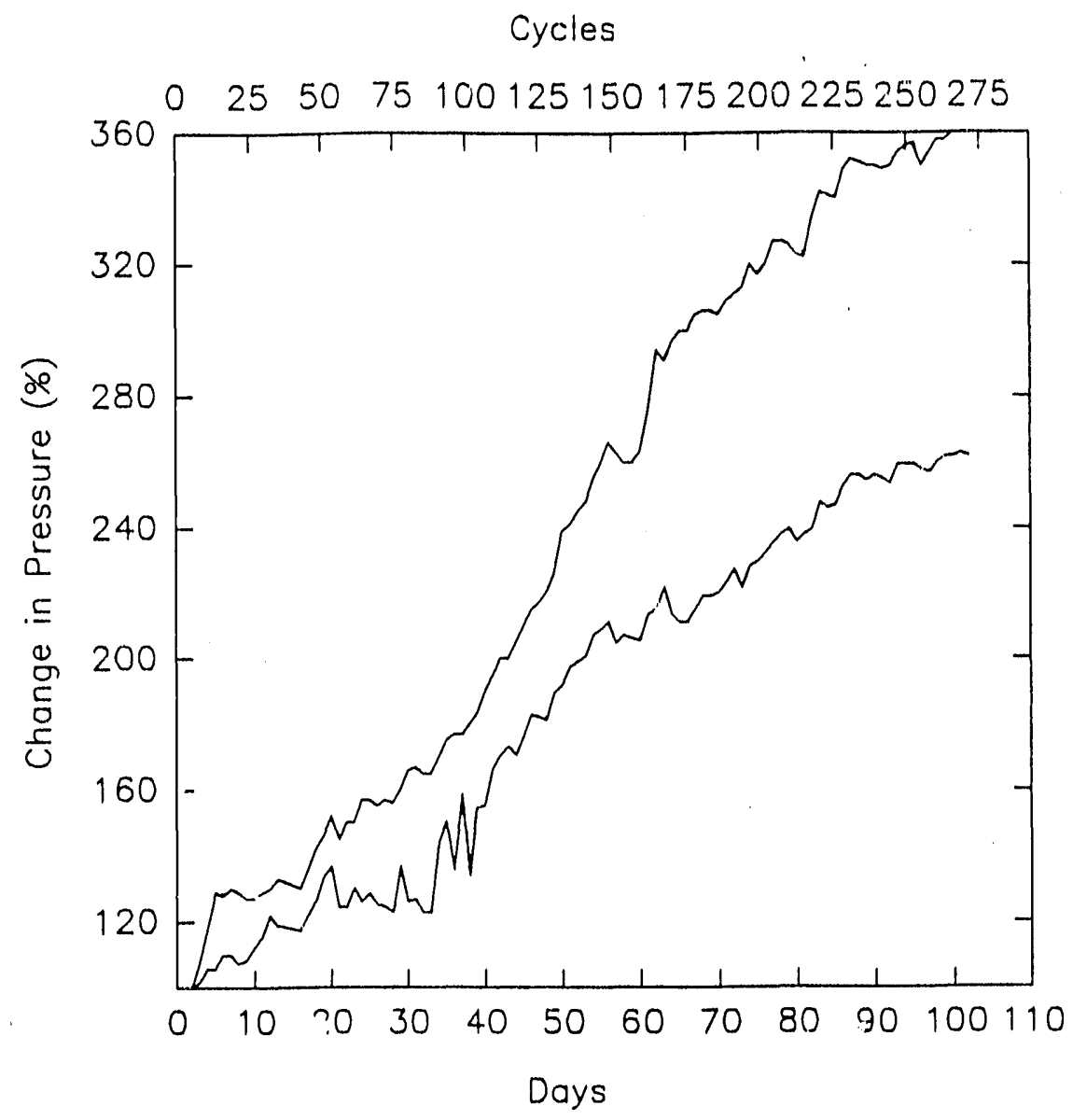

Fig. 3. Change in pressure for an ammonia/ $\mathrm{CaBr}_{2}$ complex for two connected reactors that were sequentially heated to $189^{\circ} \mathrm{C}$ and cos ed to room temperature out of phase with each other. 
Prior to post-test optical examination, all specimens were inspected to ensure that relaxation of tension by, for example, failure of the stressing bolt or crevice corrosion under the bolt or insulator, had not invalidated the test. No relaxation of tension was found.

Optical microscopic examination was performed on every specimen. None of the specimens showed any indication of localized corrosion and/or cracking. Therefore, the lifetimes of these materials should depend upon their general corrosion rates. While a rate was not specilically obtained in these tests, inferences about rates can be obtained from observations of the corrosion product. Differences in the appearance of the materials exposed to various salt complexes resulted in a corrosivity ranking (least to most) as follows: $\mathrm{SrCl}_{2} / \mathrm{NH}_{3}, \mathrm{CaBr}_{2} / \mathrm{NH}_{3}$, and $\mathrm{CaCl} / \mathrm{NH}_{3}$. The materials' ranking and appearance are presented in Table 3. All the tested matcrials had excelleni corrosion resistance to $\mathrm{SrCl}_{2} / \mathrm{NH}_{3}$ with $\mathrm{A} 214$ and $\mathrm{Al} 6063$ showing slightly grealer resistance than $\mathrm{Al} 3003$ and $\mathrm{Al}$ 1100. While $\mathrm{Al}$ 3003, $\mathrm{Al} 1100$, and $\mathrm{A} 214$ demonstrated

Table 3. Appearance of materials after exposure to salt complexes. Materials and salt complexes are listed in order of their corrosion resistance and corrosivity, respectively.

\begin{tabular}{|c|c|c|}
\hline Complex & Material $^{a}$ & Comment \\
\hline \multirow[t]{2}{*}{$\mathrm{SrCl}_{2}$} & $\begin{array}{l}\text { A214 } \\
\text { Al } 6063\end{array}$ & $\begin{array}{l}\text { Bright } \\
\text { Bright }\end{array}$ \\
\hline & $\begin{array}{l}\text { Al } 3033 \\
\text { Al } 1100\end{array}$ & $\begin{array}{l}\text { Slight staining } \\
\text { Slight staining }\end{array}$ \\
\hline \multirow[t]{3}{*}{$\mathrm{CaBr}_{2}$} & $\begin{array}{l}\text { Al } 3003 \\
\text { Al } 1100\end{array}$ & $\begin{array}{l}\text { Dull in appearance } \\
\text { Dull in appearance }\end{array}$ \\
\hline & $\mathrm{A} 214$ & Black tarnish \\
\hline & Al 6063 & $\begin{array}{l}\text { White, powdery, thick film; } \\
\text { etched appearance beneath } \\
\text { film }\end{array}$ \\
\hline \multirow[t]{3}{*}{$\mathrm{CaCl}_{2}$} & $\mathrm{~A} 214$ & Scattered red-brown stain \\
\hline & $\begin{array}{l}\text { Al } 3003 \\
\text { Al } 6063\end{array}$ & $\begin{array}{l}\text { Fincly spalled, thick film } \\
\text { Fincly spalled, thick film }\end{array}$ \\
\hline & Al 1100 & Coarsely spalled, thick film \\
\hline
\end{tabular}

\footnotetext{
$a_{\text {Materials that are not separated by a horizontal line are of equal }}$ corrosion resistance.
} 
good corrosion resistance to $\mathrm{CaBr}_{2} / \mathrm{NH}_{3}, \mathrm{Al} 6063$ developed a thick, powdery film indicating poor resistance. All the tested materials demonstrated the lowest corrosion resistance to $\mathrm{CaCl}_{2} / \mathrm{NH}_{3}$ with A214 performing best. The finely spalled, thick films on $\mathrm{Al} 3003$ and $\mathrm{Al} 6063$ may be precursors to a more coarsely spalled, thick film as observed on Al 1100. Thus, without the benclit of longer term testing and identification of corrosion products, the aluminum alloys are not recommended for use with $\mathrm{CaCl}_{2} / \mathrm{NH}_{3}$ complex.

\section{CONCLUSIONS}

Based on the results of these 2000-h thermal cyclic tests in salt/ammonia heat pump working media, the following can be concluded.

- A214, Al 6063, Al 3003, and Al 1100 showed excellent corrosion resistance to $\mathrm{SrCl} / \mathrm{NH}_{3}$ complex.

- Al 3003, Al 1100, and A214 demonstrated good corrosion resistance to $\mathrm{CaBr} 2 \mathrm{NH}_{3}$ complex.

- A214 displayed good corrosion resistance to $\mathrm{CaCl}_{2} / \mathrm{NH}_{3}$.

- The $\mathrm{CaBr}_{2} / \mathrm{NH}_{3}$ complex, which demonstrated thermal cyclic instability, is not recommended lis use as a heat pump working medium.

\section{REFERENCES}

1. L. Kirol, R. Agarwal, and U. Rockenfeller, Complex Salt Technology Application to Industrial Chemical Heat Pump, Final Report, Rocky Research Corporation, Boulder City, Nevalda, September 1989. 
ORNL/TM-12004

\section{INTERNAL DISTRIBUTION}

1-2. Central Research Library

3. Document Reference Section

4-5. Laboratory Records Department

6. Laboratory Records, ORNL-RC

7. ORNL Patent Section

8-10. M\&C Records Office

11-15. M. R. Ally

16. P. J. Blau

17. R. S. Carlsmith

18. F. C. Chen

19. D. F. Craig

20. F. A. Creswick

21-25. J. H. DeVan
26-30. M. Howell

31. M. A. Karnitz

32. J. R. Keiser

33. J. R. Mayotte

34. P. L. Rittenhouse

35. G. M. Slaughter

36-40. D. F. Wilson

41. A. D. Brailsford (Consultant)

42. Y. A. Chang (Consultant)

43. H. W. Foglesong (Consultant)

44. J. J. Hren (Consultant)

45. M. L. Savitz (Consultant)

46. J. B. Wachtman, Jr. (Consultant)

\section{EXTERNAL DISTRIBUTION}

47. BATtElle COLUMBUS labORATORIES, 505 King Avenue, Columbus, OH 43201

W. T. Hanna

48. BIERMAN, W. J., 45 Foxcroft Drive, Fayetteville, NY 13066

49. BORG-WARNER AIR CONDITIONING, INC., P.O. Box 1592, York, PA 17405

D. K. Miller

50. CALM, J. M., Consulting Engineer, P.O. Box 12014, Arlington, VA 22009-0014

51. CLARK UNIVERSITY, Professor, Goverment and Geography, Graduate School of Geography, Worcester, MA 01610

R. E. Kasperson

52. DUKE UNIVERSITY, Dean, Graduate School, 4875 Duke Station, Durham, NC 27706

S. M. Gillis

53. EG\&G-IDAHO, INC., P.O. Box 1625-WCB, Idaho Falls, ID 83415

J. I. Mills 
54. ELECTRIC POWER RESEĀKCH INSTITUTE, Vice President, P.O. Box 10412, Palo Alto, CA 94303

F. R. Kalhammer

55. ELECIRIC POWER RESEARCH INSTITUTE, Energy Management \& Utilization Division, 3412 Hillview Avenue, Palo Alto, CA 94303
A. Karp

56. ENERGY CONCEPTS CO., 62; ?idgely Avenue, Annapolis, MD 21401

D. C. Erickson

57-58. GAS RESEARCH INSTITUTE, 8800 West Bryn Mawr Avenue, Chicago, IL 60631

D. S. Severson

J. J. Tuzson

59. GEORGIA INSTITUTE OF TECHNOLOGY, Department of Mechanical Engineering, Atlanta, GA 30332

S. V. Shelton

6)-61. ROCKY RESEARCH COMPANY, 1453 Rawhide Road, Boulder City, NV 98005 U. Rockenfeller

62. TENNESSEE VALLEY AUTHORITY, 703 Power Building, Chattanooga, TN 37402

C. Douglas Carver

63. TRANE COMPANY, 3600 Pammel Creck Road, LaCrosse, WI 54601

F. C. Hayes

64. UNIVERSITY OF CALIFORNIA, Lawrence Berkelcy Laboratory, Berkeley, CA 94720

M. Wahlig

65. UNIVERSITY OF CALIFORNIA, Professor, Engineering and Applied Science, Civil Engineering Department, Engineering I, Room 2066, Los Angeles, CA 90024

R. L. Perrine

66. UNIVERSITY OF MARYLAND, Department of Mechanical Engineering, College Park, MD 20742

R. Radermacher 
67. UNIVERSITY OF TEXAS, Taylor Hall 116, Austin, TX 78712

G. C. Vliet

68. U.S. DOE, IDAHO FIELD OFFICE, 785 DOE Place, Idaho Falls, ID 83402

R. N. Chappell

69-72. U.S. DOE, OFFICE OF INDUSTRIAL TECHNOLOGIES, 1000 Independence Avenue, S.W., Forrestal Building, Washington, DC 20585

R. J. Fiskum, CE-132

S. L. Richlen, CE-141

J. D. Ryan, CE-132

A. J. Streb, Deputy Assistant Secretary

73. U.S. DOE, OFFICE OF CONSERVATION AND RENEWABLE ENERGY, CE-12 1000 Independence Avenue, S.W., Forrestal Building, Washington DC 20545

J. J. Eberhardt

74. U.S. DOE, OAK RIDGE FIELD OFFICE, P.O. Box 2008, Oak Ridge, TN 37831-6269

Assistant Manager for Energy Research and Development

75-84. DOE, OFFICE OF SCIENTIFIC AND TECHNICAL INFORMATION, P.O. Box 62, Oak Ridge, TN 37831

For distribution by microfiche as shown in DOE/OSTI-4500, Distribution Category UC-310 [Industrial Programs (General)] 

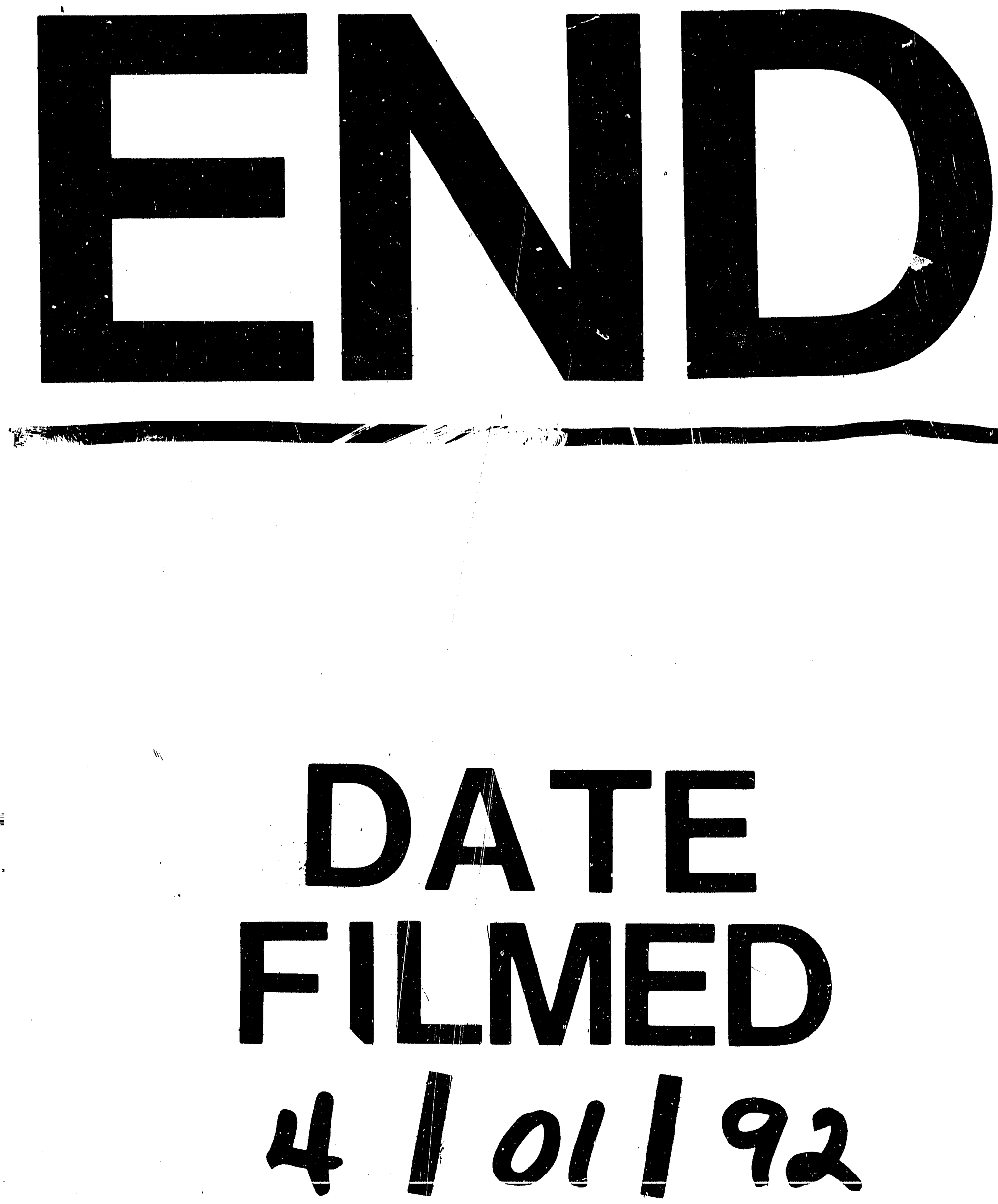

$I$ 
1 